\title{
ANALISIS PENGETAHUAN REMAJA PUTRI MENGENAI ANEMIA SEBELUM DAN SESUDAH PENYULUHAN
}

\author{
Yunni Safitri ${ }^{\bowtie}$ \\ Program Studi S1 Kebidanan STIKes Payung Negeri Pekanbaru
}

\section{ARTICLE INFO \\ Article history \\ Submitted : 2021-12-28 \\ Revised : 2022-01-06 \\ Accepted : 2022-01-12}

\section{Keywords:}

\section{Knowledge}

Young Women

Anemia

\section{Kata Kunci:}

Pengetahuan

Remaja Putri

Anemia

\begin{abstract}
Anemia is the most common nutritional issue of adolescents in Southeast Asia. About $25-40 \%$ of adolescent girls experience mild to severe levels of anemia. Lack of knowledge causes young women to be anemic as nutrition is essential for growth and development. This study aims to know the difference in adolescent girls' knowledge of anemia before and after counseling. The type of research used is quantitative with a descriptive design. The study was conducted at SMA Negeri 08 Pekanbaru on November 15, 2021. The population of this study is adolescent girls in Class X, a total of 248 people. Calculation using random stratified sampling obtained 71 respondents as the sample size in this study. Research instruments use questionnaires assessed from pretest and posttest results. Counseling on anemia was conducted before the posttest. Most of the female respondents had good knowledge before the counseling, about 54 people (76\%), and after counseling, there is an increase of up to 70 people (99\%). It can be concluded that there is an increase in the knowledge of adolescent girls about anemia after being given counseling. Educational institutions should improve health education regarding anemia in adolescent girls, such as facilitating the establishment of PIK KRR (Adolescent Reproductive Health Information and Counseling Center) or other forums that can answer student questions related to anemia and conduct health education.

Masalah gizi remaja di Asia Tenggara adalah anemia yaitu $25-40 \%$ remaja putri mengalami kejadian anemia tingkat ringan sampai berat. Kurangnya pengetahuan tentang hal tersebut menyebabkan remaja putri rentan menderita anemia karena gizi sangat diperlukan untuk pertumbuhan dan perkembangan. Jenis penelitian ini adalah kuantitatif dengan desain deskriptif. Penelitian ini dilaksanakan di SMA Negeri 08 Pekanbaru pada tanggal 15 November 2021. Populasi penelitian adalah remaja putri kelas X yang berjumlah 248 orang dengan jumlah sampel 71 orang. Teknik sampling menggunakan Stratified Random Sampling. Instrumen penelitian menggunakan kuesioner yang dinilai dari hasil pretest dan posttest. Penyuluhan mengenai anemia dilakukan sebelum posttest. Hasil penelitian menunjukkan terdapat peningkatan pengetahuan remaja putri mengenai anemia setelah diberikan penyuluhan. Pengetahuan remaja putri sebelum dilakukan penyuluhan dengan kriteria baik sebanyak 54 orang $(76 \%)$ dan sesudah dilakukan penyuluhan yang mendapat kriteria baik meningkat 70 orang (99\%). Sebaiknya institusi pendidikan meningkatkan pendidikan kesehatan khususnya mengenai anemia pada remaja putri dengan memfasilitasi wadah di sekolah seperti pembentukan PIK KRR (Pusat Informasi dan Konseling Kesehatan Reproduksi Remaja atau wadah lain yang dapat menjawab pertanyaan siswi terkait anemia dan melakukan penyuluhan Kesehatan.
\end{abstract}

\section{Corresponding Author:}

Yunni Safitri

Prodi S1 Kebidanan STIKes Payung Negeri Pekanbaru Telp. 085272106860

Email: yunnisafitri88@gmail.com

\section{PENDAHULUAN}

Anemia adalah keadaan menurunnya kadar hemoglobin, hematokrit, dan jumlah sel darah merah di bawah nilai normal yang dipatok untuk perorangan (Puspikawati et al., 2021). Masa remaja adalah periode pertumbuhan anak-anak menuju proses kematangan manusia dewasa. Pada periode ini terjadi perubahan fisik, biologis, dan psikologis
This is an open access article under the CC BY-SA license: 
negara-negara berkembang, termasuk India $55,8 \%$ dari remaja berusia $15-19$ tahun dilaporkan anemia dan 6\% di negara maju. Menurut (Hasyim, 2018) kasus anemia pada remaja saat ini mencapai prevalensi $21,7 \%$. Kasus anemia ini terdiri dari $20,6 \%$ kasus di kota dan $22,8 \%$ di desa. Kasus yang terjadi pada remaja mencapai prevalensi sebanyak $18,4 \%$.

Masalah gizi remaja di Asia Tenggara adalah anemia yaitu $25-40 \%$ remaja putri mengalami kejadian anemia tingkat ringan sampai berat (Sefaya et al., 2017). Pola makan merupakan perilaku yang mempengaruhi gizi yang kualitas dan kuantitas makanan dan minuman yang dikonsumsi akan mempengaruhi kesehatan. Gizi pola makan yang sehat dan seimbang sangat dibutuhkan untuk mendukung kelancaran aktivitas keseharian yang padat agar tidak menyebabkan anemia (Mufa, 2021).

Anemia zat besi masih lazim terjadi di negara berkembang, tidak terkecuali Indonesia (Kalsum \& Halim, 2016). Dari semua kelompok umur tersebut, wanita memiliki resiko paling tinggi untuk menderita anemia terutama remaja putri. Hasil data survei Depkes RI Tahun 2012, menunjukkan bahwa prevalensi anemia di Indonesia masih cukup tinggi. Anemia pada balita 40,5\%, pada ibu hamil $50,5 \%$, pada ibu nifas $45,1 \%$, dan remaja putri usia 10 - 18 tahun $57,1 \%$, dan usia $19-45$ tahun $39,5 \%$ (Suryani et al., 2017).

Berdasarkan data dari Dinas Kesehatan Provinsi Riau tahun 2014 diketahui bahwa kejadian anemia pada remaja putri masih banyak yaitu $(57,8 \%)$, sedangkan data dari Dinas Kesehatan Kota Pekanbaru didapatkan rekapitulasi kejadian anemia pada remaja di Kabupaten/Kota Pekanbaru terbanyak berada di Puskesmas Garuda sebanyak 79 orang. Menurut (Aramico \& Siketang, 2017) terjadinya ketidakseimbangan asupan zat gizi juga menjadi penyebab anemia pada remaja. Remaja putri mengalami menstruasi setiap bulan dan sedang dalam masa pertumbuhan sehingga membutuhkan asupan zat besi yang lebih banyak, karenanya remaja putri memiliki risiko sepuluh kali lebih besar untuk menderita anemia dibandingkan dengan remaja putra.

Pada umumnya tidak mampu memenuhi keanekaragaman zat makanan yang dibutuhkan oleh tubuhnya untuk proses sintesis pembentukan Hemoglobin $(\mathrm{Hb})$ karena memiliki kareteristik kebiasaan makan tidak sehat (Kalsum \& Halim, 2016). Kebiasaan mengemil makanan rendah gizi dan makan makanan siap saji, kebiasaan tidak makan pagi, malas minum air putih dan diet tidak sehat karena ingin langsing (mengabaikan sumber protein, karbohidrat, vitamin dan mineral). Apabila hal ini terjadi dalam jangka waktu yang lama akan menyebabkan kadar $\mathrm{Hb}$ terus berkurang dan menimbulkan anemia (Suryani et al., 2017).

Berdasarkan data Dinas Pendidikan Provinsi Riau pada Sekolah Menengah Atas (SMA) baik negeri maupun swasta di Kota Pekanbaru siswa perempuan terbanyak berada di SMAN 08 Pekanbaru sebanyak 743 orang. Berdasarkan latar belakang diatas, kurangnya pengetahuan remaja putri tentang anemia berperan terhadap kejadian anemia pada remaja putri, maka peneliti tertarik untuk melakukan penelitian tentang Analisis Pengetahuan Remaja Putri Mengenai Anemia Sebelum dan Sesudah Penyuluhan di SMAN 08 Pekanbaru Tahun 2021.

\section{METODE PENELITIAN}

\section{Jenis Penelitian}

Jenis penelitian yang digunakan adalah kuantitatif dengan desain penelitian deskriptif yaitu suatu metode penelitian yang dilakukan dengan tujuan utama untuk membuat gambaran, abalisis atau deskriptif tentang suatu keadaan secara objektif (Suryana, 2012). Penelitian ini menggambarkan pengetahuan remaja putri mengenai anemia sebelum dan sesudah penyuluhan di SMA Negeri 08 Pekanbaru.

\section{Lokasi dan Waktu Penelitian}

Berdasarkan data Dinas Pendidikan Provinsi Riau SMA negeri maupun swasta di Kota Pekanbaru siswa perempuan terbanyak berada di SMAN 08 Pekanbaru sebanyak 743 orang. Lokasi penelitian ini dilaksanakan di SMA Negeri 08 Pekanbaru. Waktu penelitian dilakukan pada tanggal 15 November 2021.

\section{Populasi dan Sampel}

Berdasarkan data dari Dinas Pendidikan Provinsi Riau jumlah siswi kelas X berjumlah 248 orang. Populasi penelitian ini adalah remaja putri kelas X yang berjumlah 248 orang di SMA Negeri 08 Pekanbaru pada saat penelitian.

Sampel adalah objek yang diteliti dan dianggap mewakili seluruh populasi ini. Sampel 
adalah sebagian dari seluruh elemen yang menjadi obyek penelitian (Hasyim, 2018).

Rumus:

$$
\mathbf{n}=\frac{\mathbf{N}}{1+\mathbf{N}(\mathbf{e})^{2}}
$$

Keterangan:

$\mathrm{N}$ : Jumlah sampel

$\mathrm{N}$ : Jumlah populasi

e : Standar error (10\%)

Besar Sampel adalah:

$$
\begin{aligned}
& \mathrm{n}=\frac{248}{1+248 \times 0,1^{2}} \\
& \mathrm{n}=\frac{248}{3,48} \\
& \mathrm{n}=71,264 \\
& \mathrm{n}=71 \text { orang }
\end{aligned}
$$

Teknik sampel yang digunakan peneliti adalah secara acak stratifikasi (Stratified Random Sampling). Sampling secara acak berlapis dilakukan jika populasi dapat dipisahpisahkan menurut lapisan tertentu dan populasinya mempunyai karakteristik yang heterogen.

Jumlah sampel yang diperlukan adalah 71 orang. Sampel diambil di kelas X di SMAN 08 Pekanbaru. Di kelas X jumlah sampel yang akan diteliti dalam 1 kelas ada 5 orang, 6 orang dan 7 orang. Jadi jumlah responden untuk masing-masing kelas ada 5 orang di kelas X IPS 1 , X IPS 3, X MIPA 1, ada 6 orang di kelas $X$ IPS 2, X MIPA 2, X MIPA 3, X MIPA 5, X MIPA 7, X MIPA 8, dan ada 7 orang di kelas X MIPA 4, X MIPA 6. Semua siswi dipilih secara acak sistematis dengan mengunakan nomor absen kelipatan 3 .

\section{Pengumpulan Data}

Pengumpulan data yang dilakukan dalam penelitian ini adalah menetapkan waktu dan tempat penelitian, peneliti memasukkan surat izin ke Dinas Pendidikan Provinsi Riau, peneliti memasukkan surat ke SMA Negeri 08 Pekanbaru, mengumpulkan sampel yang menjadi responden dalam aula SMAN 08 Pekanbaru. Peneliti memperkenalkan diri, menyampaikan maksud dan tujuan mengumpulkan responden dalam satu ruangan.
Mempersilahkan responden untuk mengisi lembaran kuesioner pre test sebelum penyuluhan selama 10 menit dan mengumpulkan kembali kuesioner pre test setelah diisi oleh responden.

Peneliti melakukan penyuluhan mengenai materi penelitian dengan menggunakan media power point yang terdapat gambar dan menampilkan video animasi tentang anemia, penyuluhan hanya dilakukan sekali dalam waktu 30 menit. Kemudian responden langsung mengisi lembar kuesioner post test sesudah penyuluhan selama 10 menit dan mengumpulkan kembali kuesioner post test setelah diisi responden. Pengumpulan data penelitian dilakukan dengan menggunakan data primer yaitu data yang diperoleh langsung dari remaja yang berada di wilayah SMAN 08 Pekanbaru dengan mengguanakan kuesioner. Pengolahan data dilakukan dengan beberapa tahapan, yaitu: editing, coding, processing dan cleaning.

\section{Pengolahan dan Analisis Data}

Analisa data dilakukan secara univariat yaitu analisa data yang dilakukan hanya untuk menggambarkan hasil frekuensi dan persentase dari penelitian yang nantinya dijadikan untuk pembahasan dan kesimpulan dengan perhitungan:

$$
\mathrm{P}=\frac{\mathrm{F}}{\mathrm{N}} \times 100 \%
$$

Keterangan :

$\mathrm{P}=$ Persentase

$\mathrm{F}=$ Jumlah jawaban kuesioner yang betul.

$\mathrm{N}=$ Jumlah item yang dicari.

Dari nilai yang diperoleh untuk variabel pengetahuan dikategorikan dengan kriteria:

a. Baik jika menjawab $16-20$ pertanyaan dari 20 pertanyaan yang diajukan dengan nilai: $>75 \%$.

b. Cukup jika menjawab 12 - 15 pertanyaan dari 20 pertanyaan yang diajukan dengan nilai: $60-75 \%$.

c. Kurang jika menjawab <12 pertanyaan dari 20 pertanyaan yang diajukan dengan nilai: $<60$.

\section{HASIL PENELITIAN}

Berdasarkan hasil penelitian yang telah dilakukan di SMA Negeri 08 Pekanbaru pada 
tanggal 15 November 2021 telah diperoleh data umum dan data khusus dari analisis pengetahuan remaja putri mengenai anemia sebelum dan sesudah penyuluhan di SMA Negeri 08 Pekanbaru tahun 2021 dengan jumlah sampel 71 Orang.

Tabel 1. Distribusi Frekuensi Responden berdasarkan Akses dan Sumber Informasi Anemia di SMA Negeri 08 Pekanbaru

\begin{tabular}{lcc}
\hline \multicolumn{1}{c}{ Variabel } & Frekuensi (n) & Persentase (\%) \\
\hline Akses Informasi & & \\
Ya & 29 & 41 \\
Tidak & 42 & 59 \\
\hline \multicolumn{1}{c}{ Jumlah } & 71 & 100 \\
\hline Sumber Informasi & & \\
Teman & 1 & 3,4 \\
Keluarga & 12 & 41,3 \\
Petugas Kesehatan & 6 & 20,7 \\
Guru & 4 & 13,8 \\
Media Sosial & 6 & 20,7 \\
\hline \multicolumn{1}{c}{ Jumlah } & 29 & 100 \\
\hline
\end{tabular}

Sumber: Data Primer Tahun 2021

Berdasarkan tabel 1. dapat diketahui bahwa sebagian besar responden tidak pernah mendapatkan informasi mengenai anemia yaitu sebanyak 42 responden (59\%). Mayoritas responden mendapatkan informasi dari keluarga yaitu sebanyak 12 responden $(41,3 \%)$. Sebagian besar pengetahuan responden mengenai pengertian anemia sebelum penyuluhan adalah baik sebanyak 43 orang $(61 \%)$ dan sesudah penyuluhan sebagian besar adalah baik sebanyak 67 orang (94\%).

Mayoritas pengetahuan responden mengenai penyebab anemia sebelum penyuluhan adalah cukup sebanyak 30 orang (42\%) dan sesudah penyuluhan sebagian besar adalah baik sebanyak 58 orang (82\%). Sebagian besar pengetahuan responden mengenai tanda dan gejala anemia sebelum penyuluhan adalah baik sebanyak 52 orang (73\%) dan sesudah penyuluhan sebagian besar adalah baik sebanyak 60 orang $(85 \%)$.

Mayoritas pengetahuan responden mengenai dampak anemia sebelum penyuluhan adalah cukup sebanyak 38 orang (54\%) dan sesudah penyuluhan sebagian besar adalah baik sebanyak 45 orang (65\%). Sebagian besar pengetahuan responden mengenai penanganan awal anemia sebelum penyuluhan adalah baik sebanyak 67 orang (94\%) dan sesudah penyuluhan sebagian besar adalah baik sebanyak 70 orang (99\%).

\section{PEMBAHASAN}

Dari hasil penelitian yang dilakukan maka diperoleh data yang merupakan keadaan nyata pada Analisis Pengetahuan Remaja Putri Mengenai Anemia Sebelum dan Sesudah Penyuluhan di SMA Negeri 08 Pekanbaru Tahun 2021. Hasil penelitian yang dilakukan pada tanggal 15 November 2021 dengan menggunakan kuesioner sebelum dan sesudah penyuluhan terdapat 71 responden diketahui bahwa sebagian besar responden remaja putri di SMA Negeri 08 Pekanbaru sebelum penyuluhan berpengetahuan baik sebanyak 54 orang (76\%) dan sesudah penyuluhan berpengetahuan baik sebanyak 70 orang (99\%). Pengetahuan remaja putri meliputi pengertian anemia sebelum penyuluhan baik sebanyak 43 orang $(61 \%)$ dan sesudah penyuluhan baik sebanyak 67 orang (94\%), penyebab anemia sebelum penyuluhan cukup sebanyak 30 orang (42\%) dan sesudah penyuluhan baik sebanyak 58 orang $(82 \%)$, tanda dan gejala anemia sebelum penyuluhan baik sebanyak 52 orang (73\%) dan sesudah penyuluhan baik sebanyak 60 orang (85\%), dampak anemia sebelum penyuluhan cukup sebanyak 38 orang (54\%) dan sesudah penyuluhan baik sebanyak 46 orang $(65 \%)$ dan penanganan awal anemia sebelum penyuluhan baik sebanyak 67 orang (94\%) dan sesudah penyuluhan baik sebanyak 70 orang $(99 \%)$. 
Tabel 2. Distribusi Frekuensi Pengetahuan Responden tentang Anemia, Pengertian Anemia, Penyebab Anemia, Tanda dan Gejala Anemia, Dampak Anemia, dan Penanganan Awal Anemia di SMA Negeri 08 Pekanbaru

\begin{tabular}{|c|c|c|c|c|}
\hline \multirow{3}{*}{ Kategori } & \multicolumn{4}{|c|}{ Pelaksanaan Penyuluhan } \\
\hline & \multicolumn{2}{|c|}{ Sebelum Penyuluhan (Pre) } & \multicolumn{2}{|c|}{ Sesudah Penyuluhan (Post) } \\
\hline & Frekuensi & Persentase (\%) & Frekuensi & Persentase $(\%)$ \\
\hline \multicolumn{5}{|c|}{ Pengetahuan Anemia } \\
\hline Baik & 54 & 76 & 70 & 99 \\
\hline Cukup & 17 & 24 & 1 & 1 \\
\hline Kurang & 0 & 0 & 0 & 0 \\
\hline Jumlah & 71 & 100 & 71 & 100 \\
\hline \multicolumn{5}{|c|}{ Pengetahuan Pengertian Anemia } \\
\hline Baik & 43 & 61 & 67 & 94 \\
\hline Cukup & 27 & 38 & 4 & 6 \\
\hline Kurang & 1 & 1 & 0 & 0 \\
\hline Jumlah & 71 & 100 & 71 & 100 \\
\hline \multicolumn{5}{|c|}{ Pengetahuan Penyebab Anemia } \\
\hline Baik & 26 & 37 & 58 & 82 \\
\hline Cukup & 30 & 42 & 11 & 15 \\
\hline Kurang & 15 & 21 & 2 & 3 \\
\hline Jumlah & 71 & 100 & 71 & 100 \\
\hline \multicolumn{5}{|c|}{ Pengetahuan Tanda dan Gejala Anemia } \\
\hline Baik & 52 & 73 & 60 & 85 \\
\hline Cukup & 17 & 24 & 11 & 15 \\
\hline Kurang & 2 & 3 & 0 & 0 \\
\hline Jumlah & 71 & 100 & 71 & 100 \\
\hline \multicolumn{5}{|c|}{ Pengetahuan Dampak Anemia } \\
\hline Baik & 33 & 46 & 46 & 65 \\
\hline Cukup & 38 & 54 & 24 & 34 \\
\hline Kurang & 0 & 0 & 1 & 1 \\
\hline Jumlah & 71 & 100 & 71 & 100 \\
\hline \multicolumn{5}{|c|}{ Pengetahuan Penanganan Awal Anemia } \\
\hline Baik & 67 & 94 & 70 & 99 \\
\hline Cukup & 4 & 6 & 1 & 1 \\
\hline Kurang & 0 & 0 & 0 & 0 \\
\hline Jumlah & 71 & 100 & 71 & 100 \\
\hline
\end{tabular}

Sumber: Data Primer Tahun 2021

Pengetahuan adalah merupakan domain yang sangat penting untuk terbentuknya tindakan seseorang. Pengetahuan merupakan hasil dari tahu, dan ini terjadi setelah orang melakukan pengindraan terhadap suatu objek tertentu. Pengindraan terjadi melalui pancaindra manusia, yakni indra penglihatan, pendengaran, penciuman, rasa, dan raba. Sebagian besar pengetahuan manusia diperoleh melalui mata dan telinga (Waluyo et al., 2019). Penyebab terjadinya kasus anemia terjadinya karena kurang pengetahuan (Mamat \& Mardianti,
2021). Remaja putri menjadi lebih rawan terhadap anemia gizi besi dibandingkan dengan laki-laki, karena remaja putri mengalami menstruasi/haid berkala yang mengeluarkan sejumlah zat besi setiap bulan. Selain itu, zat besi dibutuhkan pada masa pubertas untuk pembentukan sel-sel darah merah yang berfungsi untuk pertumbuhan. Oleh karena itu, remaja putri lebih banyak membutuhkan zat besi pada remaja putra (Samria \& Fitriani, 2022). 
Sebagian besar responden remaja putri di SMA Negei 08 Pekanbaru tidak mendapatkan informasi mengenai anemia sebanyak 42 orang (59\%). Pengetahuan remaja putri mengenai anemia sebelum penyuluhan di SMA Negeri 08 Pekanbaru berada dalam kategori baik yang dilatar belakangi salah satu faktor SMA Negeri 08 termasuk SMA terbaik di Provinsi Riau dan anemia juga dipelajari pada mata pelajaran biologi, sedangkan yang pernah mendapatkan informasi sebanyak 29 orang $(41, \%)$ didapatkan dari keluarga sebanyak 12 orang $(41,3 \%)$.

Menurut (Sefaya et al., 2017) faktorfaktor yang mempengaruhi tingkat pengetahuan seseorang adalah pendidikan, pekerjaaan, umur, pengalaman, kebudayaan lingkungan sekitar dan informasi. Kemudahan untuk memperoleh informasi dapat mempercepat seseorang memperoleh pengetahuan yang baru. Lingkungan sangat berpengaruh dalam pembentukan sikap, tempat kita hidup dan dibesarkan mempunyai pengaruh besar terhadap pembentukan sikap kita. Hal ini sesuai dengan mayoritas responden mendapatkan informasi dari lingkungan sekitar (keluarga) (Basith et al., 2017).

Penyuluhan kesehatan adalah kegiatan pendidikan kesehatan, yang dilakukan dengan menyebarkan pesan, menanamkan keyakinan, sehingga masyarakat tidak hanya sadar, tahu dan mengerti, tetapi juga mau dan bisa melakukan suatu anjuran yang ada hubungannya dengan kesehatan (Waluyo et al., 2019). Menurut (Sari \& Anggraini, 2020) media dapat meningkatkan efektivitas pada proses pendidikan dan konseling karena manfaat media yang paling utama adalah memperjelas pesan-pesan yang akan disampaikan, karena sebagian besar remaja tidak tahu atau tidak menyadari akibat dari anemia. Bahkan mereka menganggap anemia sebagai masalah yang tidak penting dan tidak perlu mendapatkan perhatian khusus.

Remaja putri di Indonesia banyak yang mengalami anemia dikarenakan kurang mengkonsumsi makanan dari sumber protein hewani yang kaya zat besi dan mudah diserap tubuh (hemeiron). Apabila jumlah zat besi di dalam tubuh berkurang dapat menimbulkan hambatan dalam pertumbuhannya baik sel tubuh maupun sel otak. Apabilah dalam darah kadar $\mathrm{Hb}$ berkurang dapat menimbulkan gejala tubuh merasa cepat capek, lemah, letih, lelah dan lesu. Adapun akibat dari gejala anemia tersebut adalah prestasi belajar remaja dapat menurun, malas berolahraga dan produktivitas kerja menurun, serta imunitas tubuh menurun sehingga tubuh mudah terinfeksi. Bagi remaja yang sudah bekerja maka produktivitas kerja dapat menurun apabila mengalami anemia, sedangkan remaja yang masih sekolah maka kemampuan akademis dapat menurun (Hafiza et al., 2021).

Penyuluhan kesehatan dengan menggunakan media power point dan video animasi dapat meningkatkan pengetahuan responden (Sari \& Anggraini, 2020). Penyuluhan dengan menggunakan media video lebih efektif meningkatkan pengetahuan dibandingkan dengan menggunakan media power point. Pengetahuan remaja putri mengenai anemia di SMA Negeri 08 Pekanbaru sebelum penyuluhan adalah baik dan sesudah penyuluhan adalah baik.

\section{KESIMPULAN DAN SARAN}

Gambaran pengetahuan remaja putri mengenai anemia sebelum penyuluhan baik sebanyak 54 orang (76\%) dan sesudah penyuluhan berpengetahuan baik sebanyak 70 orang (99\%). Gambaran pengetahuan remaja putri mengenai pengertian anemia sebelum penyuluhan baik sebanyak 43 orang $(61 \%)$ dan sesudah penyuluhan baik sebanyak 67 orang (94\%). Gambaran pengetahuan remaja putri mengenai penyebab anemia sebelum penyuluhan cukup sebanyak 30 orang (42\%) dan sesudah penyuluhan baik sebanyak 58 orang $(82 \%)$. Gambaran pengetahuan remaja putri mengenai tanda dan gejala anemia sebelum penyuluhan baik sebanyak 52 orang (73\%) dan sesudah penyuluhan baik sebanyak 60 orang $(85 \%)$. Gambaran pengetahuan remaja putri mengenai dampak anemia sebelum penyuluhan cukup sebanyak 38 orang (54\%) dan sesudah penyuluhan baik sebanyak 46 orang $(65 \%)$. Gambaran pengetahuan remaja putri mengenai penanganan awal anemia sebelum penyuluhan baik sebanyak 67 orang (94\%) dan sesudah penyuluhan baik sebanyak 70 orang (99\%).

Diharapkan institusi pendidikan dapat meningkatkan pendidikan kesehatan khususnya mengenai anemia pada remaja putri dengan memfasilitasi wadah di sekolah seperti pembentukan PIK KRR (Pusat Informasi dan Konseling Kesehatan Reproduksi Remaja) atau 
wadah lain yang dapat menjawab pertanyaan terkait anemia dan melakukan penyuluhan kesehatan. Diharapkan peneliti selanjutnya dapat meningkatkan media penyuluhan tidak hanya menggunakan media power point dan video animasi namun juga memberikan buku saku dan media lainnya.

\section{DAFTAR PUSTAKA}

Aramico, B., \& Siketang, N. W. (2017). Hubungan Asupan Gizi, Aktivitas Fisik, Menstruasi Dan Anemia Dengan Status Gizi Pada Siswi Madrasah Aliyah Negeri (MAN) Simpang Kiri Kota Subulussalam. Sel Jurnal Penelitian Kesehatan, 4(1), 21-30. https://doi.org/10.22435/sel.v4i1.1444.

Basith, A., Agustina, R., \& Diani, N. (2017). Faktor-Faktor Yang Berhubungan Dengan Kejadian Anemia Pada Remaja Putri. Dunia Keperawatan, 5(1), 1. https://doi.org/10.20527/dk.v5i1.3634.

Hafiza, D., Utmi, A., \& Niriyah, S. (2021). Hubungan Kebiasaan Makan Dengan Status Gizi Pada Remaja SMP YLPI Pekanbaru. Al-Asalmiya Nursing Jurnal Ilmu Keperawatan (Journal of Nursing Sciences), 9(2), 86-96. https://doi.org/ 10.35328/keperawatan.v9i2.671.

Hasyim, D. I. (2018). Aktivitas Fisik Dengan Kejadian Anemia Pada Remaja Putri. Keperawatan Dan Kebidanan Aisyiyah, 14(1), 6-14.

Kalsum, U., \& Halim, R. (2016). Kebiasaan Sarapan Pagi Berhubungan dengan Kejadian Anemia Pada Remaja di SMA Negeri 8 Muaro Jambi. Jurnal Penelitian Universitas Jambi Seri Sains, 18(1), 0919. https://www.academia.edu/38524920/

Mamat, \& Mardianti. (2021). The Effect of Reproductive Health Nutrition Pocket Bookon Anemia Prevention Interestof Worker Women. Jurnal Riset Kesehatan, 13(1), 57-63. https://doi.org/ 10.34011/juriskesbdg.v13i1.1858.

Mufa, N. A. (2021). Pola Makan Dan Gejala Anemia Pada Mahasiswa Perantauan Di Universitas Samudra. Jurnal Jeumpa, 7(2), 458-461. https://doi.org/ 10.33059/jj.v7i2.3796.

Puspikawati, S. I., Sebayang, S. K., Made, D.,
\& Kurnia, S. (2021). Pendidikan Gizi tentang Anemia pada Remaja di Kecamatan Banyuwangi Jawa Timur Nutrition Education about Anemia in Adolescents in Banyuwangi District, East Java. August.

Samria, \& Fitriani, L. (2022). Pengaruh Penyuluhan Kesehatan tentang Anemia terhadap Pengetahuan dan Kepatuhan Siswi Remaja Mengkonsumsi Tablet FE. JKA (Jurnal Keperawatan Abdurrab), 05(02), 30-40. https://doi.org/ 10.36341/jka.v5i2.2110.

Sari, M. H. N., \& Anggraini, D. D. (2020). Penyuluhan dan Deteksi Dini Anemia menuju Generasi Berkualitas pada Mahasiswa Kebidanan. Jurnal Empathy, 1(1), 72-84. https://doi.org/ 10.37341/jurnalempathy.v1i1.13.

Sefaya, K., Nugraheni, S., \& Pangestuti, D. (2017). Pengaruh Pendidikan Gizi Terhadap Pengetahuan Gizi Dan Tingkat Kecukupan Gizi Terkait Pencegahan Anemia Remaja (Studi Pada Siswa Kelas Xi Sma Teuku Umar Semarang. Jurnal Kesehatan Masyarakat (e-Journal), 5(1), 272-282.

Suryana. (2012). Metodologi Penelitian: Metodologi Penelitian Model Praktis Penelitian Kuantitatif dan Kualitatif. In Universitas Pendidikan Indonesia.

Suryani, D., Hafiani, R., \& Junita, R. (2017). Analisis Pola Makan Dan Anemia Gizi Besi Pada Remaja Putri Kota Bengkulu. Jurnal Kesehatan Masyarakat Andalas, 10(1), $\quad 11 . \quad$ https://doi.org/ 10.24893/jkma.v10i1.157.

Waluyo, D., Hidayanty, H., \& Seweng, A. (2019). Pengaruh Pendidikan Gizi Anemia Terhadap Peningkatan Pengetahuan Pada Anak Remaja Sma Negeri 21 Makassar. Jurnal Kesehatan Masyarakat Maritim, 1(3), 301-306. https://doi.org/10.30597/jkmm.v1i3.8821. Yunarsih, Y., \& Antono, S. D. (2017). Hubungan Pola Menstruasi Dengan Kejadian Anemia pada Remaja Putri Kelas VII SMPN 6 Kediri. Jurnal Ilmu Kesehatan, 3(1), 25. https://doi.org/ 10.32831/jik.v3i1.42. 